\title{
EQUATIONS TO PREDICT THE METABOLIZABLE ENERGY OF MEAT AND BONE MEAL FOR GROWING PIGS
}

\author{
Equações para predizer a energia metabolizável da farinha de carne e \\ ossos para suínos em crescimento
}

\author{
Ricardo Araújo Castilho ${ }^{1}$, Paulo Cesar Pozza ${ }^{2}$, Newton Tavares Escocard de Oliveira ${ }^{3}$, \\ Cleiton Pagliari Sangali ${ }^{2}$, Carolina Natali Langer ${ }^{3}$, Ricardo Vianna Nunes $^{3}$
}

\begin{abstract}
The prediction of metabolizable energy (ME) of meat and bone meal (MBM) for pigs is an interesting tool, however, used models to predict these values must be validated in order to garantee higher precision. The aim of this study was to determine the chemical and energetic composition of different types of MBM for pigs and to adjust and validate models to better predict the ME based on the chemical composition. Thirty-two barrows, averaging an initial weight of $26.75 \pm 1.45 \mathrm{~kg}$, were individually allotted in a randomized block design with eight treatments and four replicates. The treatments consisted of seven types of MBM that replaced $20 \%$ of the basal diet. A stepwise procedure was the statistical procedure used to adjust the prediction equations and the ME was the dependent parameter. The validation of the adjusted models was performed using an independent databank of chemical and energetic composition of theBrazilian and international MBM. The metabolizable energy of different meat and bone meals ranged from 1645 to $2645 \mathrm{kcal} \mathrm{kg}^{-1}$. The equations that provide a good prediction of metabolizable energy of meat and bone meal for swine in Brazil are $\mathrm{EM}_{1}=-4233.58+0.4134 \mathrm{GE}+72 \mathrm{CP}+89.62 \mathrm{ash}-159.06 \mathrm{Ca} ; \mathrm{EM}_{2}=2087.49+0.3446 \mathrm{GE}+31.82 \mathrm{ash}-189.18 \mathrm{Ca} ; \mathrm{EM}_{3}=2140.13$ $+0.3845 \mathrm{GE}-112.33 \mathrm{Ca} ; \mathrm{EM}_{4}=-346.58+0.656 \mathrm{GE} ; \mathrm{EM}_{5}=3221.27+178.96 \mathrm{fat}-76.55 \mathrm{ash} ;$ and $\mathrm{EM}_{6}=5356.45-84.75 \mathrm{ash}$.
\end{abstract}

Index terms: Chemical composition; regression equation; slaughterhouse by-products.

\section{RESUMO}

A predição dos valores de energia metabolizável (EM) da farinha de carne e ossos (FCO) para suínos é uma ferramenta interessante, mas os modelos usados para predizer esses valores devem ser validados para garantir maior precisão. Objetivou-se com este trabalho, determinar a composição química e energética de diferentes FCO para suínos; ajustar e validar modelos de predição da EM, a partir da composição química, e validar os modelos, utilizando um conjunto de dados independentes. Foram utilizados 32 suínos machos e castrados, com peso médio inicial de $26,75 \pm 1,45 \mathrm{~kg}$, distribuídos individualmente em delineamento experimental de blocos ao acaso, com oito tratamentos e quatro repetições. Os tratamentos consistiram em sete diferentes FCO que substituíram em $20 \%$ a ração referência. Para o ajuste das equações de predição, foi utilizado o procedimento estatístico Stepwise, em que a EM foi a variável dependente. Os valores de EM das FCO variaram de 1645 a $2645 \mathrm{kcal} \mathrm{kg}^{-1}$. As equações que, eficientemente, estimaram a EM da FCO, em condições brasileiras, foram: EM1 $=-4233,58+0,4134 \mathrm{~EB}+72 \mathrm{~PB}+89,62 \mathrm{MM}-159,06 \mathrm{Ca}$; EM2 $=2087,49+0,3446 \mathrm{~EB}+31,82 \mathrm{MM}-189,18 \mathrm{Ca} ; \mathrm{EM} 3=2140,13+0,3845 \mathrm{~EB}-112,33 \mathrm{Ca} ; \mathrm{EM} 4=-346,58+0,656 \mathrm{~EB} ;$ e EM5 $=$ $3221,27+178,96 \mathrm{EE}-76,55 \mathrm{MM}$ e EM6 $=5356,45-84,75 \mathrm{MM}$.

Termos para indexação: Composição química; equação de regressão; subprodutos de abatedouros.

\section{INTRODUCTION}

Swine diets basically consist of corn and soybean meal, but alternative ingredients, such as meat and bone meal (MBM), can be obtained in industrialized slaughterhouses units and utilized. However, attention must be paid whenusing animal byproducts because the nutritional values vary according to the processing, type and proportions of the constituents (Gomes et al., 2007).

Therefore, to formulate more efficient diets for pigs and adequately provide nutritional requirements, adequate knowledgeof the energetic values of the feedstuffs is necessary and can be determined by direct and indirect methods. Direct or conventional methods require a calorimeter and require metabolic assays, which are laborious, time consuming and costly methodologies and difficult for the industry to use (Sakomura; Rostagno, 2007; Pozza et al., 2008).

Equations to predict metabolizable energy (ME) utilize an indirect method, which is based on the chemical composition of the raw material routinely obtained in laboratories and isconsidered a fast, practical

\footnotetext{
${ }^{1}$ Safeeds Nutrição Animal - Rodovia PR-182 - Jardim Porto Alegre - 85906-300 - Toledo - PR - Brasil - ricardo@safeeds.com.br 2Universidade Estadual de Maringá/UEM - Departamento de Zootecnia/DZO - Maringá - PR - Brasil

${ }^{3}$ Universidade Estadual do Oeste do Paraná/UNIOESTE - Marechal Cândido Rondon - PR - Brasil

Received in may 6, 2015 and approved in september 9, 2015
} 
and economical alternative to the nutritional assessment of raw material (Ferreira; Fialho; Teixeira, 1997). The chemical composition is the main determinant of gross energy and the prediction equations can be used to improve the accuracy of thediet formulation, especially in the correction of the energy values of raw material with large chemical variation (Rostagno et al., 2011).

The use of prediction equations by the feed industry is important to estimate the energy values of feedstuffs and to adjust the nutritional values of raw material (Santos; Freitas; Fialho, 2005), but a validation procedure is necessary to assume that a prediction equation is effective in estimating the ME content. Regarding precision and accuracy, most mathematical models have good predictive power for the original data set (Oliveira; Warpechowski, 2009). However, there are a few studies that have compared the performance of prediction models in independent data sets.

The objectives of this study were to determine the chemical composition and ME of different types of MBM to fit and validate models to predict the ME of the MBM for pigs.

\section{MATERIAL AND METHODS}

The experiment was conducted in the swine metabolism room at theUniversidadeEstadual do Oeste do Paraná - UNIOESTE. Twenty-two crossbred barrows (Landrace $\times$ Large White $\times$ Piétrain), averaging an initial weight of $26.75 \pm 1.45 \mathrm{~kg}$, were individually housed in metabolic cages. The animals were distributed in arandomized blocks design with eight treatments and four replicates.

The treatments consisted of seven types of MBMthat replaced $20 \%$ of the basal diet (Table 1) and were formulated to achieve the nutritional requirements proposed by Rostagno et al. (2011). Barrows were fed a pre-established amount twice a day (at 0700 and $1700 \mathrm{~h}$ ) and according to the metabolic weight $\left(\mathrm{kg}^{0.75}\right)$.

The experiment consisted of a seven day adaptation period, followed by five days of total feces and urine collection. Ferric oxide $\left(\mathrm{Fe}_{2} \mathrm{O}_{3}\right)$ was used as a fecal marker to define the beginning and end of the collection period.

The feces were collected daily (7:30 and 5:30 $\mathrm{pm})$ and weighed and stored $\left(-5^{\circ} \mathrm{C}\right)$. After defrosting, the homogenized samples were dried $\left(55^{\circ} \mathrm{C}-72\right.$ hours), grinded and the dry matter and gross energy (GE) content was determined. The urine was collected in buckets with $20 \mathrm{ml}$ of $1: 1 \mathrm{HCl}$, filtered and a $10 \%$ sample of the total volume was stored $\left(3{ }^{\circ} \mathrm{C}\right)$ for the GE determination.
The MBMs were analyzedfor dry matter (DM), crude protein (CP), ether extract (EE), GE, crude fiber (CF), mineral matter (MM), calcium (Ca) and phosphorus (P) as described by Silva and Queiroz (2005). The analysis of protein digestibility in pepsin (PEP), $\mathrm{NaOH}$ acidity and geometric mean diameter (GMD) were performed according to the techniques described by Brugalli (1999). The GE of the MBM, basal diet, feces and urine were determined at the Universidade Estadual de Maringá - UEM using an adiabatic calorimeter (Parr $\left.{ }^{\circledR}-6200\right)$.

The digestible energy (DE), metabolizable energy (ME), digestibility coefficients of GE (DCGE),metabolizability coefficients of GE (MCGE), and ME: DE ratio were determined. The DCGE and MCGE were analyzed using the Student Newman Keuls test.

To adjust the prediction equations of ME, the full multiple linear regression model was adjusted using GE, $\mathrm{CP}$, Fat, Ash, $\mathrm{Ca}$ and $\mathrm{P}$ as regressors using the ordinary minimum square method. Subsequently, the models were fitted using CP, Fat and Ash as regressors.

The selection ofregressors was conductedusing techniques of indirect elimination (Backward). The main selection criteria were the parameters' significance for the regression models and verified by the " $t$ " partial test. Then, the non-significant parameters were removed from the model and the analysis was repeated. The model adjustment quality for the ME energy data was reviewed by the determination coefficient $\left(\mathrm{R}^{2}\right)$.

To validate the adjusted prediction equations, a database was compiled containing 48 pairs of observed and predicted ME. The 48 observed ME values were compiled from the literature (Adedokun; Adeola, 2005; Pozza et al., 2008; Olukosi; Adeola, 2009; Rostagno et al., 2011) and classified according to the scientific origin, which resulted in 15 data values from the Brazilian experiments and 33 others were obtained from the international literature. The 48 predicted values of ME were obtained by inputting the chemical composition of the MBMs found in the literature (on the DM basis) into the prediction equations adjusted in this study.

The validity of the regression models was initially assessed by adjusting the linear regression of the 1 st degree $\left(y i=b_{0}+b_{1} x_{i}+\varepsilon i\right)$ of the observed ME (y) in the function of the estimated ME (x) and using the ordinary least squares analysis. This procedure was adopted for the databases from the Brazilian, international and mixed (Brazilian and international) literature. 
Table 1: Centesimal composition of the basal diet as a feed basis.

\begin{tabular}{lc}
\hline \multicolumn{1}{c}{ Ingredients } & Amount (\%) \\
\hline Corn & 68.45 \\
Soybean meal & 27.29 \\
Dicalcium phosphate & 1.51 \\
Limestone & 0.84 \\
Oil & 0.72 \\
Salt (NaCl) & 0.43 \\
L-Lysine $\mathrm{HCl}(78.40 \%)$ & 0.34 \\
DL-Methionine (98.0\%) & 0.10 \\
L-Threonine (98.0\%) & 0.09 \\
L-Tryptophan (98.0\%) & 0.01 \\
Mineral-vitamin premix * & 0.20 \\
Antioxidant $* *$ & 0.01 \\
Growth promoter *** & 0.006 \\
\hline
\end{tabular}

\begin{tabular}{lc}
\hline \multicolumn{2}{c}{ Calculated composition } \\
\hline Metabolizable energy (kcal/kg) & 3230 \\
Crude protein (\%) & 18.158 \\
Crude fiber (\%) & 2.631 \\
Calcium (\%) & 0.768 \\
Available phosphorus (\%) & 0.380 \\
Sodium (\%) & 0.200 \\
Digestible lysine (\%) & 1.093 \\
Digestible methionine+cystine (\%) & 0.612 \\
Digestible tryptophan (\%) & 0.197 \\
Digestible threonine (\%) & 0.689 \\
*Guaranteed level per kg of product: vit. A -10,000,000 IU; vit D3 - 2,000,000 IU; vit. E - 60,000 IU; vit. B1 - 1.0 g; vit. B2 - 5.0 \\
g; vit. B6 - 2.0 g; vit. B12 - 30.000 mcg; nicotinicacid - 30.000 mcg; pantothenicacid - 15.000 mcg; vit. K3 - 1.000 mg; folicacid \\
- 1.500 mg; biotin - 250 mg; selenium - 350 mg; iron - 100 g; copper - 10 g; cobalt - $\mathrm{g}$; manganese - 50 g; zinc - 100 g; iodine -1 \\
g; andcarrier q.s. for 1000 g, ** Butylatedhydroxytoluene,and ***Tylosinphosphate 25\%.
\end{tabular}

The existence of a linear relationship between the observed and estimated values was evaluated by detecting the significance of the $\beta_{1}$ parameter estimative (angular coefficient), which was verified by applying the partial " $\mathrm{t}$ " test to evaluate the null hypothesis $\mathrm{H}_{0}: \beta_{\mathrm{i}}$ $=0$. The rejection of the null hypothesis for the angular coefficient suggested the influence of the estimated $\mathrm{ME}$ values to explain the variation in the observed ME values.

The prediction validation of the regression models of 1 st degree, and therefore the validation of the estimated equations as predictors of the linear ratio of ME from the chemical composition values of MBM for pigs was checked by adjusting a linear regression model of the 1st degree of the predicted values $\left(\hat{\mathrm{y}}=\mathrm{b}_{0}+\mathrm{b}_{1} \mathrm{x}_{\mathrm{i}}\right)$ of ME by the equations initially estimated in function of the observed values.

The joint nullity hypothesis for the parameters of the linear regression ( $\mathrm{H} 0: \beta 0=0$ and $\beta 1=1$ ) was tested. The validation of the equations was observed when $\mathrm{H} 0$ was not rejected when applying the F test (Montgomery; Peck; Vining, 2006), indicating similarities between observed $(\mathrm{y})$ and predicted $(\mathrm{Y})$ values, that is, low magnitude in the residue values $(\varepsilon i=y-\hat{y})$. 
A significance level of $5 \%(\mathrm{P}<0.05)$ was used for all hypotheses, and statistical analyses were performed using the Statistical Analysis System (Statiscal Analysis System Institute-Sas, 2002).

\section{RESULTS AND DISCUSSION}

All of the studied MBMsshowedamoisturecontent (Table 2) below the maximum limit (8.0\%) reported in the CompêndioBrasileiro de Alimentação Animal (2009).

The average CP content (Table 2) ranged from 40.73 to $50.28 \%$ and is close to the values proposed by Rostagno et al. (2011), which classified the MBMs into nine groups according to protein content $(36,38,41,44,46$, $48,50,55$ and $63 \% \mathrm{CP})$. The meat and bone meals showed a protein content above the minimum (40.0\%) established by Associação Nacional dos Fabricantes de Rações-Anfar (1985) and reported in the CompêndioBrasileiro de Alimentação Animal (2009).

The ash levels of the MBMs ranged from 31.90 to $44.66 \%$ (Table 2). The ash content of the different MBMs was inversely proportional to the $\mathrm{CP}$, which was observed in other literature (Nunes et al., 2005; Pozza et al., 2008; Rostagno et al., 2011), and this ratio is a result of the inclusion of the bones and tendon tissues (Seerley, 1991; Nunes et al., 2005).

The evaluated MBMscannot be classified as defatted, which must have a minimum of $2 \%$ and the maximum of $4 \%$ fat (Anfar, 1985); the fat levels ranged from 8.68 to $12.07 \%$ (Table 2).

The calcium $(\mathrm{Ca})$ and phosphorus $(\mathrm{P})$ ranged from 10.41 to $15.84 \%$ and 5.17 to $7.62 \%$, respectively (Table 2), and the Ca: P ratio ranged from 1.96 to 2.15. Despite the variability, the $\mathrm{Ca}$ and $\mathrm{P}$ levels are in accordance with the recommendations and standardization of Divisão de Fiscalização de Alimentos para Animais-Difisa (1989) because they presented values higher than $3.8 \%$. Similarly, the maximum Ca: $\mathrm{P}$ ratio should be 2.15:1 (Compêndio Brasileiro de Alimentação Animal, 2009), and all of the evaluated batches met this recommendation.

This chemical composition variation was expected due to the differences in the processing techniques and in the raw material used in the manufacturing of MBM. Brumano et al. (2006) and Gomes et al. (2007) noted the need to be cautious when using animal byproducts because of the low standardization of these products, which undergo variations in composition and the processing and the type and proportions of their constituents.

The pepsin digestibility of the MBMsranged from 48.12 to $80.78 \%$ (Table 2) and are above the minimum (30\%) established by the Compêndio Brasileiro de Alimentação Animal (2009). The acidity in $\mathrm{NaOH}$ demonstrated a good quality of the studied MBMs because all of the batches showed a maximum of $3.0 \mathrm{mEqNaOH} 0.1 \mathrm{~N} 100 \mathrm{~g} \mathrm{~g}^{-1}$, which was reported by Anfar (1985) as a standard recommendation.

The DCGE ranged from 56.17 to $69.01 \%$ (Table 3). This variation was expected due to the differences obtained in the chemical composition of the MBMs. MBM 1 showed a higher DCGE $(\mathrm{P}<0.05)$ compared with MBMs 4 and 7, which may be related to the higher $\mathrm{CP}$ and fat levels. In addition, the MBMs 4 and 7 showed higher amounts of Ash, $\mathrm{Ca}$ and $\mathrm{P}$ than MBM 1, which may have also contributed to the lower DCGE.

Table 2: The chemical composition, pepsin digestibility, $\mathrm{NaOH}$ acidity and particle size of different meat and bone meals (MBMs) as a feed basis.

\begin{tabular}{lrrrrrrr}
\hline \multicolumn{1}{c}{ Parameters } & \multicolumn{7}{c}{ MBM } \\
\cline { 2 - 8 } & \multicolumn{1}{c}{1} & \multicolumn{1}{c}{2} & \multicolumn{1}{c}{3} & \multicolumn{1}{c}{5} & \multicolumn{1}{c}{6} & \multicolumn{1}{c}{7} \\
\hline Dry matter (\%) & 96.38 & 95.12 & 94.08 & 97.25 & 92.09 & 92.66 & 96.61 \\
Crude protein (\%) & 50.28 & 49.97 & 44.77 & 48.62 & 44.20 & 45.30 & 40.73 \\
Fat (\%) & 12.07 & 10.41 & 11.43 & 9.10 & 9.77 & 8.68 & 10.08 \\
Crude fiber (\%) & 2.21 & 1.91 & 2.67 & 2.68 & 3.22 & 2.94 & 1.82 \\
Ash (\%) & 35.51 & 31.90 & 38.04 & 36.58 & 37.35 & 37.51 & 44.66 \\
Calcium (\%) & 11.42 & 10.41 & 12.16 & 13.43 & 13.03 & 13.17 & 15.84 \\
Phosphorus (\%) & 5.72 & 5.17 & 6.19 & 6.25 & 6.21 & 6.48 & 7.62 \\
Pepsin digestibility 0.002 (\%) & 79.71 & 77.06 & 70.63 & 62.77 & 54.79 & 80.78 & 48.12 \\
NaOH Acidity (meq 100 $\mathrm{g}^{-1}$ ) & 0.34 & 2.05 & 1.28 & 0.16 & 0.55 & 0.49 & 0.46 \\
Particle Size ( $\mu \mathrm{m})$ & 853 & 1262 & 933 & 809 & 1083 & 1045 & 999 \\
\hline
\end{tabular}

Ciênc. Agrotec., Lavras, v. 39, n. 6, p. 565-573, nov./dez., 2015 
The metabolizable energy ranged from 1645 to 2645 $\mathrm{kcal} \mathrm{kg}^{-1}$, whichare in accordance with the values observed by Pozza et al.(2008). However, the average ME values obtained by Adedokun andAdeola (2005) were higher, which may be related to the higher CP content ( $\min 50 \%$ ) of the MBMs studied by these authors, and a lower ash content was also observed.

The variability observed in ME is partially due to the MCGE (Table 3) obtained for the different MBM. MBM 7 showed a low MCGE $(p<0.05)$ compared with MBMs 1, 3 and 6, which may be related to the protein quality of the samples. Therefore, whether the protein is low quality or in excess, there is increased nitrogen loss, which leads to increased energy expenditure for $\mathrm{N}$ excretion and a reduction of the amount of energy available to the animal (Pozza et al, 2008; Olukosi;Adeola, 2009).

The correlation matrix (Table 4) obtained by the adjustment of the prediction equations of the full model, shows that the ME values were negatively correlated with the ash and positively with the $\mathrm{CP}$, which was also reported in the literature (Johnson; Parsons, 1997; Adedokun;Adeola, 2005; Pozza et al., 2008; Olukosi;Adeola, 2009; Rostagno et al, 2011). According to Ewans (1991), the energetic concentration depends on carbohydrates, fats, proteins, ash and water, and it should be emphasized that water and ash do not contribute to the energy content. The negative effect of ash on the energy values of the MBMs may be due to the dilutive effect of GE, which reduces the organic content of the feedstuff (Morgan; Whittemore; Phillips, 1987). Similarly, calcium and phosphorus were also negatively correlated with ME.

There was a positive correlation between thefat and ME (Table 4), which was different from the results obtained by Pozza et al. (2008) thatshowed a negative correlation. In that study, the authors attributed the findings of negative correlation to high ash levels because beyond the dilutive effect, the ash can also reduce the digestibility of some compounds such as fats (Noblet; Perez, 1993).

Table 3: Gross (GE), digestible (DE) and metabolizable (ME) energy, digestibility (DCGE) and metabolizability (MCGE) coefficients of the GE and the ME:DE ratio of meat and bone meals (MBMs) for pigs as a feed basis.

\begin{tabular}{ccccccc}
\hline MBM & GE $(\mathrm{kcal} / \mathrm{kg})$ & $\begin{array}{c}\mathrm{DCGE}^{1} \\
(\%)\end{array}$ & $\begin{array}{c}\mathrm{DE} \\
(\mathrm{kcal} / \mathrm{kg})\end{array}$ & $\begin{array}{c}\mathrm{MCGE}^{1} \\
(\%)\end{array}$ & $\begin{array}{c}\mathrm{ME} \\
(\mathrm{kcal} / \mathrm{kg})\end{array}$ & ME:DE \\
\hline 1 & 4142 & $69.01 \mathrm{a}$ & 2859 & $62.36 \mathrm{a}$ & 2583 & 0.90 \\
2 & 4704 & $62.67 \mathrm{abc}$ & 2948 & $56.23 \mathrm{ab}$ & 2645 & 0.90 \\
3 & 3613 & $66.11 \mathrm{ab}$ & 2389 & $57.96 \mathrm{a}$ & 2094 & 0.88 \\
4 & 3248 & $59.89 \mathrm{bc}$ & 1945 & $55.26 \mathrm{ab}$ & 1795 & 0.92 \\
5 & 3482 & $61.73 \mathrm{abc}$ & 2149 & $56.00 \mathrm{ab}$ & 1950 & 0.91 \\
6 & 3134 & $63.03 \mathrm{abc}$ & 1975 & $58.45 \mathrm{a}$ & 1832 & 0.93 \\
7 & 3338 & $56.17 \mathrm{c}$ & 1875 & $49.29 \mathrm{~b}$ & 1645 & 0.88 \\
$\mathrm{CV}(\%)$ & - & 6.29 & - & 6.18 & - & - \\
\hline
\end{tabular}

${ }^{1}$ Averages followed by different letters in the same column differ by the SNK test $(\mathrm{P}<0.05)$. CV: Coefficient of variation.

Table 4: The correlation of the chemical composition and energy values of the meat and bone meals.

\begin{tabular}{cccccccc}
\hline Item & ME & GE & CP & Fat & Ash & Ca & P \\
\hline ME & 1.00000 & - & - & - & - & - & - \\
GE & 0.89234 & 1.00000 & - & - & - & - & - \\
CP & 0.74405 & 0.62647 & 1.00000 & - & - & - & - \\
Fat & 0.60320 & 0.56817 & 0.20928 & 1.00000 & - & - & - \\
Ash & -0.75508 & -0.70101 & -0.96110 & -0.14473 & 1.00000 & - & - \\
Ca & -0.87949 & -0.81852 & -0.89764 & -0.44642 & 0.93357 & 1.00000 & - \\
P & -0.83512 & -0.78615 & -0.94222 & -0.32805 & 0.98039 & 0.97697 & 1.00000 \\
\hline
\end{tabular}

ME (metabolizable energy), GE (gross energy), CP (crude protein), Ca (calcium), P (phosphorus). 
The determination coefficients $\left(\mathrm{R}^{2}\right)$ obtained when adjusting prediction equations using the complete model, ranged from 0.80 to 0.90 and ranged from 0.57 to 0.82 when using the $\mathrm{CP}$, fat and ash to adjust the models (Table 5). The higher number of variables in the model provided higher $\mathrm{R}^{2}$ values, and the equation $\mathrm{EM} 1=-4233.58+0.41339 \mathrm{GE}$ $+71.999 \mathrm{CP}$ Ash + 89.6191Ash - 159.062Ca presented the highest $\mathrm{R}^{2}(0.90)$. This result indicates that $90 \%$ of the variation in the ME content of the MBMs are explained by the independent variables that make up this equation.

The predicted ME values, using the adjusted models (Table 5), showed differences with the values observed in metabolism assays (Figure 1) when using the chemical composition of the MBMs obtained in these studies to estimate the ME. This variance could happen despite the great effort to develop prediction models, which do not always attempt to relate the chemical composition with energy content even though this has been successful when tested with independent data, which may be associated with variability between laboratories even when the same analytical technique is used (Cromwell et al., 1999).

Furthermore, the chemical composition of the MBMs is dependent on the raw materials used, different systems, temperature and time for processing the MBMs (Shirley; Parsons, 2000), which partially explains the variation observed between the predicted $\mathrm{ME}$, using the adjusted prediction equations, and the ME values observed in other metabolism assays.

All of the adjusted models showed satisfactory prediction for the ME of MBMs (Figure 1). The joint nullity hypothesis $\left(\mathrm{H}_{0}: \beta_{0}=0\right.$ and $\left.\beta_{1}=1\right)$ was acceptedfor equations $\mathrm{EM}_{1}, \mathrm{EM}_{2}, \mathrm{EM}_{3}, \mathrm{EM}_{4}, \mathrm{EM}_{5}$ and $\mathrm{EM}_{6}$ when tested on data from the Brazilian literaturebut was not accepted when tested on data from the international or mixed literature.

The angles formed by the lines of the 1 st degree with the $x$-axis (Figure 1) were not different $(p>0.05)$ from the angles described by the ideal lines $\left(45^{\circ}\right)$, which indicated the similarity of the predicted $(\mathrm{y})$ and observed $(\mathrm{x})$ values. The maximum absolute residual values observed $(y-\hat{y})$ were $210,245,247,605,653$ and 248 kcal kg-1. Despite the variation in the composition of Brazilian MBM, the F test was sensitive enough to confirm the $\mathrm{H}_{0}$ acceptance.

All of the fitted models were validated and can be used to obtain more accurate values of ME in Brazilian conditions once the average values of $\mathrm{ME}$, estimated from Brazilian literature data, did not differ from the values observed in the respective metabolism trial.

The prediction equation that showed the highest $\mathrm{R}^{2}(0.90)$ wasEM $_{1}=-4233.58+0.41339 \mathrm{GE}+71.999 \mathrm{CP}$ $+89.6191 \mathrm{ash}-159.062 \mathrm{Ca}$ (Figure 1a). However, the equation $\mathrm{EM}_{5}=3221.27+178.962$ fat $-76.5533 \mathrm{ash}$ (Figure 1e) showed a low $\mathrm{R}^{2}(0.82)$ and was convenient for conducting the laboratory tests because it does not use calciumand does not require an adiabatic calorimeter.

The adjusted equations showed a maximum of four chemical composition parameters, which is of great importance because the equations composed of up to four chemical composition parameters require a shorter time, are easier and the determination of economy can be easily used (Pozza et al., 2008). Similarly, Rodrigues, Rostagno and Albino (2002) reported that the use of prediction equations to determine the ME of feed was composed of only one or a combination of chemical composition parameters, which requirea lower number of laboratory analysis.

Table 5: Intercepts, coefficients of regression and determination of the equations to predict the metabolizable energy (ME) of the meat and bone meals for pigs on a dry matter basis.

\begin{tabular}{|c|c|c|c|c|c|c|c|c|}
\hline \multirow{2}{*}{ Equations } & \multirow{2}{*}{ Intercept } & \multicolumn{6}{|c|}{ Regression coefficients } & \multirow{2}{*}{$\mathrm{R}^{2}$} \\
\hline & & GE & $\mathrm{CP}$ & Fat & Ash & $\mathrm{Ca}$ & $\mathrm{P}$ & \\
\hline \multicolumn{9}{|c|}{ Adjusted equations using the complete model } \\
\hline $\mathrm{ME}_{1}$ & -4233.58 & 0.41339 & 71.999 & - & 89.6191 & -159.062 & - & 0.90 \\
\hline $\mathrm{ME}_{2}$ & 2087.49 & 0.34460 & - & - & 31.8207 & -189.184 & - & 0.87 \\
\hline $\mathrm{ME}_{3}$ & 2140.13 & 0.38451 & - & - & - & -112.333 & - & 0.86 \\
\hline $\mathrm{ME}_{4}$ & -346.58 & 0.656 & - & - & - & - & - & 0.80 \\
\hline \multicolumn{9}{|c|}{ Adjusted equations using CP, Fat and Ash } \\
\hline $\mathrm{ME}_{5}$ & 3221.27 & - & - & 178.962 & -76.5533 & - & - & 0.82 \\
\hline $\mathrm{ME}_{6}$ & 5356.45 & - & - & - & -84.7450 & - & - & 0.57 \\
\hline
\end{tabular}

GE (gross energy), CP (crude protein), Ca (calcium), P (phosphorus), and $\mathrm{R}^{2}$ (coefficient of determination). 


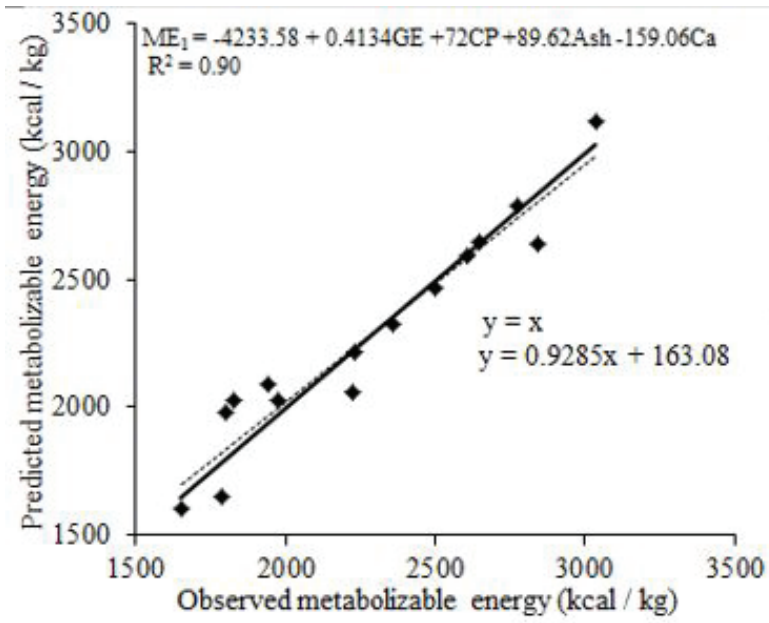

(a)

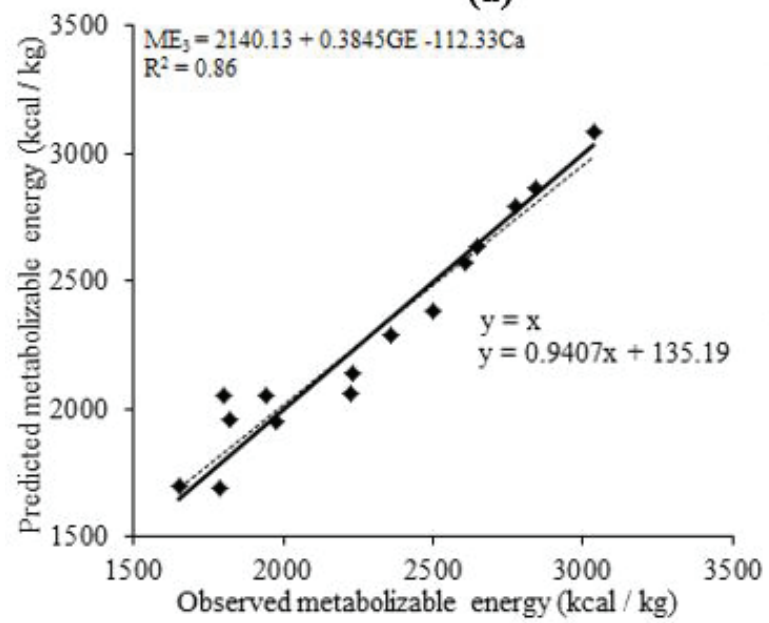

(c)

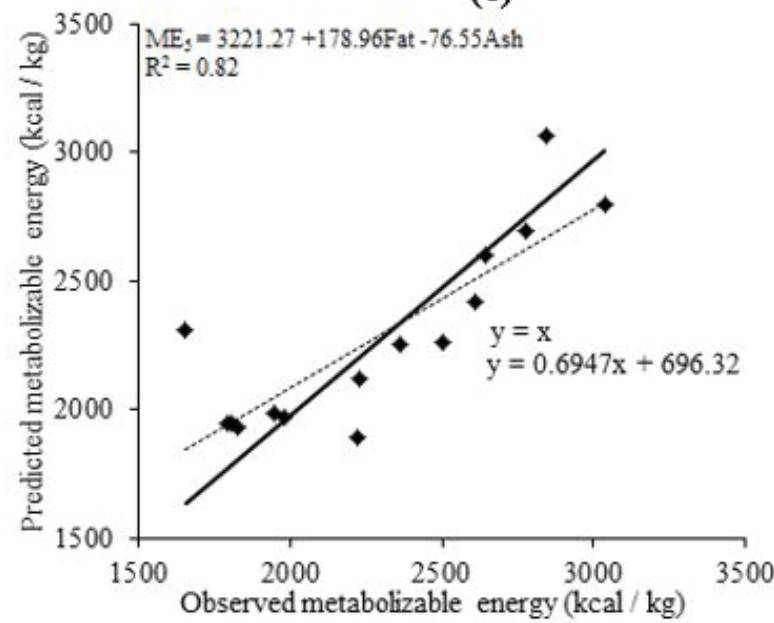

(e)

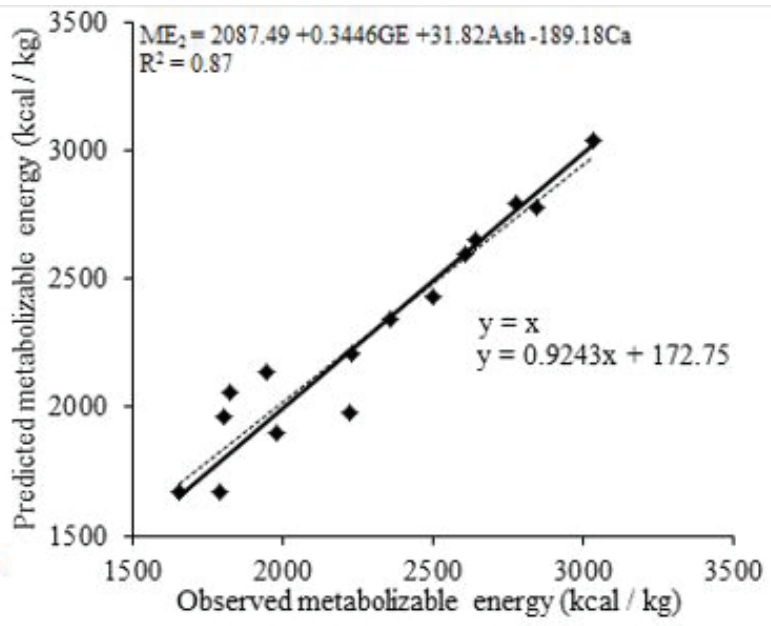

(b)

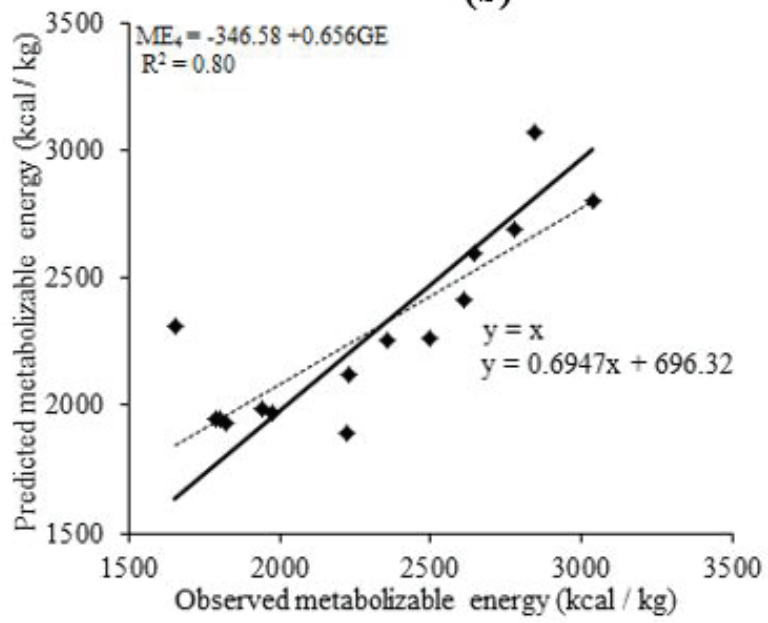

(d)

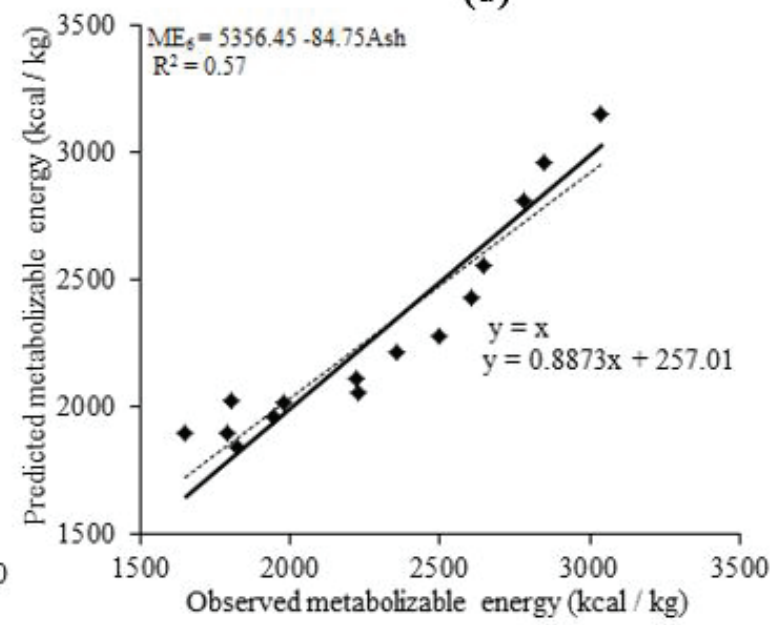

(f)

Figure 1: The metabolizable energy (ME) predicted by equations $\operatorname{ME}_{1}(\mathrm{a}), \mathrm{ME}_{2}(\mathrm{~b}), \mathrm{ME}_{3}(\mathrm{c}), \mathrm{ME}_{4}(\mathrm{~d}), \mathrm{ME}_{5}(\mathrm{e})$ and $\mathrm{ME}_{6}(\mathrm{f})$ due to the $\mathrm{ME}$ values of meat and bone meal for swine and obtained in the Brazilian literature. 
However, when evaluating the models using data from international and mixed literature (Brazilian and international), the joint nullity hypothesis ( $\mathrm{H} 0: \beta 0=0$ and $\beta 1=1$ ) was rejected, that is, the equations EM1, EM2, EM3, EM4, EM5 and EM6 did not have a satisfactory prediction with the maximum absolute residuals $(\mathrm{y}-\hat{\mathrm{y}})$ of 1323, 1189, 1161, 1194, 1094 and $1145 \mathrm{kcal} \mathrm{kg}^{-1}$, respectively, for data from the international literature and 1118, 1252, 1122, 1234, 1277 and $1140 \mathrm{kcal} \mathrm{kg}^{-1}$, respectively, for the data from the mixed literature.

There was no validation of the prediction equations when using an independent databank obtained in other countries, which is possibly due to the differences in standardization and the raw material used to produce the MBM.

The fact that the models developed in our study do not adjust to the data of ME from the international literature may be the result of several factors. According to Weiss (1993), the models are a "dependent population" and the use of models should be restricted to samples with similar characteristics of the original populationto avoid biased estimates. There is also the presupposition for most models that establishlinear relationships between the chemical composition and the energy values of feed, in which the coefficients of digestibility of the nutrients does not vary or present low variation. However, several studies suggest that variations in the digestibility of the fractions composing the MBM as fat, protein and amino acids can occur (Knabe; La Rue; Gregg, 1989; Wan; Parsons, 1998; Pozza et al., 2004; Rostagno et al., 2011).

\section{CONCLUSIONS}

The metabolizable energy of different meat and bone meals ranged from 1645 to $2645 \mathrm{kcal} \mathrm{kg}^{-1}$. The equations that provide a good prediction of metabolizable energy of meat and bone meal for pigs in Brazilian situations are $\mathrm{EM}_{1}=-4233.58+0.4134 \mathrm{GE}+72 \mathrm{CP}+$ 89.62ash $-159.06 \mathrm{Ca} ; \mathrm{EM}_{2}=2087.49+0.3446 \mathrm{GE}+$ $31.82 \mathrm{ash}-189.18 \mathrm{Ca} ; \mathrm{EM}_{3}=2140.13+0.3845 \mathrm{GE}-$ 112.33Ca; $\mathrm{EM}_{4}=-346.58+0.656 \mathrm{GE} ; \mathrm{EM}_{5}=3221.27$ +178.96 fat $-76.55 \mathrm{ash}$; and $\mathrm{EM}_{6}=5356.45-84.75 \mathrm{ash}$.

\section{REFERENCES}

ADEDOKUN, S. A.; ADEOLA, O. Metabolizable energy value of meat and bone meal for pigs. Journal of Animal Science. 83(11):2519-2526, 2005.

\section{ASSOCIAÇÃO NACIONAL DOS FABRICANTES DE RAÇÕES - ANFAR. Matérias-primas para}

alimentação animal. Padrão ANFAR. 4.ed. São Paulo: ANFAR, 1985. 65p.

BRUGALLI, I. et al. Efeito do tamanho de partícula e do nível de substituição nos valores energéticos da farinha de carne e ossos para pintos de corte.

Revista Brasileira de Zootecnia. 28(4):753-757, 1999.

BRUMANO, G. et al. Composição química e valores de energia metabolizável de alimentos protéicos determinados com frangos de corte em diferentes idades. Revista

Brasileira de Zootecnia. 35(6):2297-2302, 2006.

\section{COMPÊNDIO BRASILEIRO DE ALIMENTAÇÃO}

ANIMAL. São Paulo: SINDIRAÇÕES. 2009. 383p.

CROMWELL, G. L. et al. Variability among sources and laboratories in nutrient analyses of corn and soy bean meal. Journal of Animal Science. 77:3262-3273, 1999.

\section{DIVISÃO DE FISCALIZAÇÃO DE ALIMENTOS PARA ANIMAIS - DIFISA. Padrões oficiais de matérias-primas destinadas à alimentação animal. Brasília, 1989. 40p.}

EWANS, R. C. Energy utilization in swine nutrition. In: MILLER, E. R.; ULREY, D. E.; LEWIS, A. J. Swine nutrition. Burtterworth- Heinemann, p.121-132, 1991.

FERREIRA, E. R. A.; FIALHO, E. T.; TEIXEIRA, A. S. et al. Avaliação da composição química e determinação de valores energéticos e equação de predição de alguns alimentos para suíno. Revista Brasileira de Zootecnia. 26(3):514-523, 1997.

GOMES, F. A. et al. Valores energéticos de alguns alimentos utilizados em rações para codornas japonesas. RevistaBrasileira de Zootecnia. 36(2):396-402, 2007.

JOHNSON, M. L.; PARSONS, C. M. Effects of raw material source, ash content, and assay length on protein efficiency ratio and net protein ratio values for animal protein meals.Poultry Science.76:1722-1727, 1997.

KNABE, D. A.; LA RUE, E. J.; GREGG, E. J. Apparent digestibility of nitrogen and amino acids in protein feedstuffs by growing pigs. Journal of Animal Science. 67:441-458, 1989. 
MONTGOMERY, D. C.; PECK, E. A.; VINING, G. G. Introduction to linear regression analysis. 4. ed. New York: John Wiley \& Sons, 2006. 612p.

MORGAN, C. A.; WHITTEMORE, C. T.; PHILLIPS, P.; CROOKS, P. The prediction of the energy value of compounded pig foods from chemical analysis.Animal Feed Science Technology. 17:81-107, 1987.

NOBLET, J.; PEREZ, J. M. Prediction of digestibility of nutrients and energy values of pig diets from chemical analysis.Journalof Animal Science.71:3389-3398, 1993.

NUNES, R. V. et al. Valores energéticos de subprodutos de origem animal para aves. Revista Brasileira de Zootecnia. 34(4):1217-1224, 2005.

OLIVEIRA, V.; WARPECHOWSKI, M. Avaliação de modelos para predição da energia metabolizável do milho para aves. Ciência Rural. 39:1514-1520, 2009.

OLUKOSI, O. A.; ADEOLA, O. Estimation of the metabolizable energy content of meat and bone meal for swine. Journalof Animal Science. 87:2590-2599, 2009.

POZZA, P. C. et al. Digestibilidade ileal aparente e verdadeira de aminoácidos de farinhas de carne e ossos para suínos. Revista Brasileira de Zootecnia. 33(5):1181-1191, 2004.

POZZA, P. C. et al. Composição química, digestibilidade e predição dos valores energéticos da farinha de carne e ossos para suínos. Acta

Scientiarum. Animal Sciences. 30(1):33-40, 2008.

RODRIGUES, P. B. et al. Valores energéticos da soja e subprodutos da soja, determinados com frangos de corte e galos adultos. Revista Brasileira de Zootecnia. 31:1771-1782, 2002.
ROSTAGNO, H. S. et al. Tabelas brasileiras para aves e suínos: composição de alimentos e exigências nutricionais. 3.ed. Viçosa: Universidade Federal de Viçosa, 2011. 252p.

SAKOMURA, N. K.; ROSTAGNO, H. S. Métodos de pesquisa em nutrição de monogástricos. Jaboticabal SP. FUNEP, 2007. 283p.

SANTOS, Z. A. S.; FREITAS, R. T. F.; FIALHO, E. T. Valor nutricional de alimentos para suínos determinado na Universidade Federal de Lavras. Ciência e Agrotecnologia. 29(1):232-237, 2005.

SEERLEY, R. W. Major feedstuffs used in swine diets. In: MILLER, E. R.; ULLREY, D. E.; LEWIS, A. J. (Eds.) Swine nutrition. Butterworth: Heinemann, 1991. p.509-516.

SILVA, D. J.; QUEIROZ, A. C. Análise de alimentos: métodos químicos e biológicos. 3.ed. Viçosa, MG: Editora UFV, 2005. 235p.

SHIRLEY, R. B.; PARSONS, C. M. Effect of pressure processing on amino acid digestibility of meat and bone meal for poultry. Poultry Science. 79:1775-1781, 2000.

STATISTICAL ANALYSIS SYSTEM INSTITUTE SAS Institute. SAS/STAT User's guide 9.0. Cary, N.C.: SAS Institute Inc, 2002.

WANG, X.; PARSONS, C. M. Effect of raw material source, processing systems, and processing temperatures on amino acid digestibility of meat and bone meals.

Poultry Science. 77:834-841, 1998.

WEISS, W. P. Prevailing concepts in energy utilization by ruminants. Journal of Dairy Science. 76:1802-1811, 1993. 